The University of Southern Mississippi

The Aquila Digital Community

Faculty Publications

$1-1-2003$

\title{
Effects of Weather on Autumn Hawk Movements at Fort Morgan,
} Alabama

\author{
Stefan Woltmann \\ University of Southern Mississippi, Harpagus@yahoo.com \\ David Cimprich \\ University of Southern Mississippi, dcimprich@tnc.org
}

Follow this and additional works at: https://aquila.usm.edu/fac_pubs

Part of the Biology Commons

\section{Recommended Citation}

Woltmann, S., Cimprich, D. (2003). Effects of Weather on Autumn Hawk Movements at Fort Morgan, Alabama. Southeastern Naturalist, 2(3), 317-326.

Available at: https://aquila.usm.edu/fac_pubs/8681

This Article is brought to you for free and open access by The Aquila Digital Community. It has been accepted for inclusion in Faculty Publications by an authorized administrator of The Aquila Digital Community. For more information, please contact Joshua.Cromwell@usm.edu. 


\title{
EFFECTS OF WEATHER ON AUTUMN HAWK MOVEMENTS AT FORT MORGAN, ALABAMA
}

\author{
Stefan WoltmanN ${ }^{1,2, *}$ AND DAVID CimPrich ${ }^{1,3}$
}

\begin{abstract}
Migrating hawks were observed at Fort Morgan, Alabama during autumn 1995-1998. The three most abundant migrants were Sharp-shinned Hawk (Accipiter striatus), Broad-winged Hawk (Buteo platypterus) and American Kestrel (Falco sparverius). The three species accounted for $84 \%$ of all observations. Most individuals ( $>80 \%$ ) were seen heading west. Compared with days with east and south winds, days with north winds were associated with significantly higher passage rates for all species, and passage rates of Broadwinged Hawks were significantly higher on days when both a cold front and north winds occurred than on days with north winds only. Hawks flew higher on east winds than on north and south winds, suggesting that hawks fly lower in winds that may blow them out over the Gulf of Mexico.
\end{abstract}

\section{INTRODUCTION}

Perhaps because hawk watching long has been a popular pastime with both amateur and professional ornithologists, the effects of weather on hawk migration have received particular attention. Much of the discussion has revolved around the influence of wind speed, wind direction and especially the passage of cold fronts. Alerstam (1978) and Richardson $(1978,1990)$ provide extensive reviews of the effects of weather on bird migration.

During autumn in northern California and in Pennsylvania, there is a positive relationship between the passage of cold fronts and the observed passage rates of several species of raptor (Allen et al. 1996, Hall et al. 1992). In Arizona, Millsap and Zook (1983) found that cold-front passage had a positive effect on observed accipiter passage rates, even though frontal passage did not appreciably affect weather conditions measured on the ground. In a study from Maryland, visibility was the only weather variable consistently correlated with increased observed passage rates (Titus and Mosher 1982). Data collected using a combination of radar and traditional ground-based observers with binoculars has shown that wind direction influences the height of migrating raptors, but

\footnotetext{
${ }^{1}$ Department of Biological Sciences, Box 5018, The University of Southern Mississippi, Hattiesburg, MS 39564. ${ }^{2}$ Present address - Department of Ecology and Evolutionary Biology, 310 Dinwiddie Hall, Tulane University, New Orleans, LA, 70118. ${ }^{3}$ Present address - The Nature Conservancy, Fort Hood Project Office, Rod and Gun Club Loop, Building 1939, Ft. Hood, TX 76544. *Corresponding author - harpagus@yahoo.com.
} 
does not necessarily influence passage rates (Evans and Lathbury 1973; Kerlinger and Gauthreaux 1984, 1985; Kerlinger et al. 1985). These studies have made it clear that hawks often fly at heights that make them difficult or impossible to consistently detect with binoculars.

The effect of large bodies of water as barriers to migration has also been studied in some detail (e.g., Evans and Lathbury 1973, Kerlinger 1984, Richardson 1975). Most raptors avoid crossing large barriers when possible, but some species do not. Peregrine Falcons (Falco peregrinus), for example, appear to regularly cross the Gulf of Mexico (Fuller et al. 1998). Although Sharp-shinned Hawks and other small raptors are capable of "island-hopping" (Anders 1991, Kerlinger 1989, MacRae 1985); many Sharp-shinned Hawks at Cape May, NJ avoided crossing even the relatively small $(<20 \mathrm{~km})$ Delaware Bay under certain conditions (Kerlinger 1984). At Cape May, Sharp-shinned Hawks flew lower when winds were from the west, presumably to avoid being blown out over the Atlantic Ocean (Kerlinger and Gauthreaux 1984, Kerlinger 1989).

We used data collected at a site in coastal Alabama to answer the following questions: (1) What is the predominant direction of hawk migration at this site? and (2) Do movement patterns match those of hawk flights in more northerly areas? Specifically, are flights associated with cold fronts, and do hawks fly lower on days when they are at risk of being blown over the Gulf of Mexico?

\section{METHODS}

\section{Study Area and Data Collection}

The study site ("Ft. Morgan"), which is on the $1.5 \mathrm{~km}$-wide, eastwest Fort Morgan peninsula in southern Alabama ( $30^{\circ} 10^{\prime} \mathrm{N}, 88^{\circ} 00^{\prime} \mathrm{W}$ ), is bordered to the north by Mobile Bay, and to the south by the Gulf of Mexico (Fig 1). A more detailed description of habitats present is presented by Woltmann (2001).

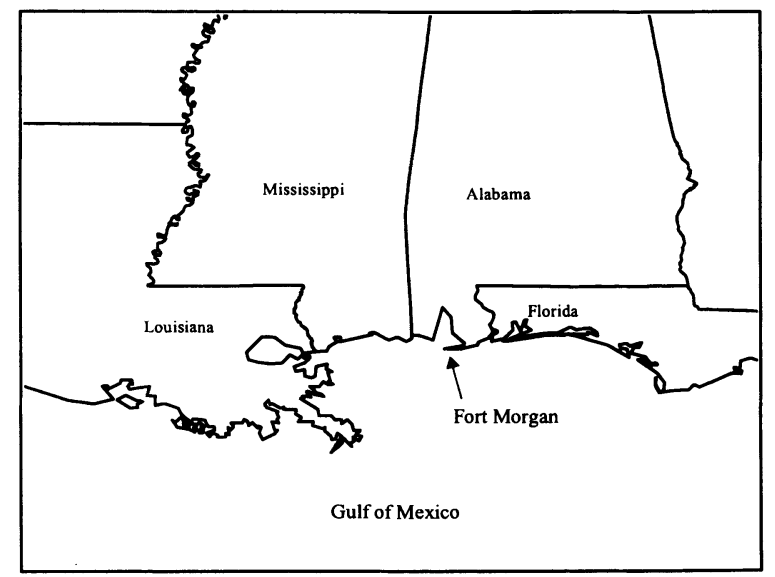

Figure 1. The Fort Morgan, Alabama study site along the northern coast of the Gulf of Mexico. 
Hawk counts were conducted from a $3 \mathrm{~m}$-high dune ridge in the Fort Morgan Unit of Bon Secour National Wildlife Refuge, approximately $1.5 \mathrm{~km}$ from the western end of the peninsula. The site allowed a clear view in all directions. Observations were made from early September to late October, 1995-1998. Counts were made by one observer; a different person was the counter every year except 1996 and 1997. Observers counted for only 30 minutes each hour (see below), reducing eye strain and fatigue from intense sun.

Hawks were counted during six, 30-minute count periods each day. Counts were not conducted during heavy rain, lightning, or hurricanes. The first count began at sunrise, the second count began one hour after sunrise, the third two hours after sunrise, and so on until the sixth hour after sunrise. Starting time was adjusted weekly to account for changing sunrise time. During each count, an observer recorded all passing raptors. Data recorded included species, age and sex (where possible), time, direction of flight (toward east or west), and height ( $<20 \mathrm{~m}, 20-40 \mathrm{~m}$ or $>40 \mathrm{~m}$ ). A stand of pines to the north and east of the observer facilitated height estimation of hawks: the pine trees were $20 \mathrm{~m}$ high, thus birds could quickly be estimated as either flying below tree height, within two times tree height, or greater than twice tree height. It was often possible to recognize individual birds, or follow individual birds that passed the observer more than once on a given day. When calculating daily passage rates, all birds suspected of being counted more than once were omitted from analyses. Still, an unknown proportion of birds were likely counted more than once.

Weather data were obtained from National Oceanic and Atmospheric Administration (NOAA) Local Climatological Data Summaries for Mobile Airport, approximately $50 \mathrm{~km} \mathrm{NNW}$ of the study site. Weather conditions were recorded at the site, but some measurements such as wind speed and direction were strongly affected by microhabitat features around the observer, and often were not representative of conditions aloft. Data from Mobile Airport, while perhaps not identical to those at the site, provided a more accurate measurement of local weather at the scale likely to influence hawk migration and were thus used for all analyses.

\footnotetext{
ANALYSES

We restricted our analyses to observations of Sharp-shinned Hawk, Broad-winged Hawk, and American Kestrel. Together, these species represent the majority ( $84 \%$ ) of hawks counted during the study. Analyses are based on data collected between 16 September and 28 October in all years, the period during which $95 \%$ of all individuals were observed. Numbers of birds counted were converted to birds $\mathrm{hr}^{-1}$. Passage data were first examined for directional trends (i.e., the majority of birds
} 
headed in one direction) between years; trends were the same for all years and all data were subsequently pooled. Individual Sharp-shinned Hawks and American Kestrels could potentially over-winter at the site; however, given the large numbers of individuals observed, the relatively small land area of the peninsula, and the fact that very few raptors were observed on non-flight days late in the season, we are confident that the vast majority of our data derive from migrating birds.

We defined a "cold front" event as the day of frontal passage (as determined from NOAA weather maps) and the following day, because the effect of the front was detectable both in terms of lower temperature and higher pressure for an average of two days, beginning on the day of frontal passage. Summary weather data from Mobile Airport were archived every six hours. For most analyses, we used weather data collected at 12:00 h to represent the conditions for the day because the majority (75\%) of hawk observations took place between 09:00-12:30 h. For analyses of the height of birds relative to weather conditions, we used weather data from 06:00 h for all hawk observations before 09:00 $\mathrm{h}$, and weather data from 12:00 h for all observations after 09:00 h. For analyses including wind direction, winds were assigned to the closest cardinal direction (e.g., an east wind originates between $45^{\circ}$ and $135^{\circ}$ ). In order to increase statistical power, hawk observations during westerly, calm or variable winds were excluded. These conditions were uncommon, occurring during $13 \%$ of raptor observations.

To determine whether higher passage rates during north winds were simply an artifact of an association between cold fronts and north winds, we compared mean daily passage rates of the three species under four conditions: (1) front present, no-north wind, (2) front present, north wind, (3) no front present, no north wind and (4) no front present, north wind. After transforming passage rates according to the formula: $\ln (n+1)$, where $\mathrm{n}$ is the mean number of birds $\mathrm{hr}^{-1}$ (following Allen et. al 1996, Hussell 1985, and Titus and Mosher 1982), the data still did not meet the assumption of homogeneity of variances. We nonetheless used a parametric test in this case because parametric ANOVA is considered robust to the assumption of homogeneity of variances if discrepant variances are not associated with either the larger or smaller samples (Tabachnick and Fidell 1996 p. 48; Zar 1999 p. 185); our data satisfied this condition

The decreased ability of an observer to detect birds against a cloudless sky is a potential source of bias if cloudless conditions are associated with certain weather conditions. Cloud cover was scored by NOAA in five categories: $1=0-10 \%, 2=11-30 \%, 3=31-60 \%, 4=61-95 \%, 5$ $=>95 \%$. Mean cloud cover at Ft. Morgan during the fall is independent of wind direction (Kruskal-Wallis ANOVA $\chi^{2}=4.08, \mathrm{P}=0.13$ ), and we conclude that decreased detectability of hawks on cloudless days did not systematically bias our observations. 
All tables and figures present untransformed means ( \pm 1 Std. Error). Statistical tests were computed with SPSS 9.0 (SPSS 1999) on a PC. For ANOVA tests, data were tested for homogeneity of variances with Levene's test. Some data failed to meet the assumption of homogeneity of variances even after transformation; non-parametric Kruskal Wallis (K-W ANOVA) tests were used in some cases. Parametric ANOVA tests were followed with Tukey tests to determine which means differed (Zar 1999); K-W ANOVA tests were followed with the Tukey-type multiple comparison test described by Zar (1999, p.223). Results were considered significant when $\mathrm{P}<0.05$ or its adjusted equivalent when conducting multiple comparisons.

\section{RESULTS}

Most Sharp-shinned Hawks, Broad-winged Hawks, and American Kestrels observed at Ft. Morgan flew west (Wilcoxon Matched-Pairs Signed-Ranks test on east and west passage rates, all $\mathrm{P}<0.001$ ), and all subsequent analyses use westward passage rates. To assess the influence of wind direction on passage rates, we first tested for differences between passage rates on days with different predominant wind directions. For these three species, mean passage rates on days with north winds were significantly higher than days with east or south winds (K-W ANOVA: Sharp-shinned Hawk $\chi^{2}=12.0, \mathrm{P}=.003$; Broad-winged Hawk $\chi^{2}=19.2$, $\mathrm{P}<0.001$; American Kestrel $\left.\chi^{2}=30.4, \mathrm{P}<0.001\right)$. Mean wind speed at Ft. Morgan during autumn is relatively low $\bar{X}=4.3 \mathrm{~m} \mathrm{~s}^{-1}, \mathrm{SE}=0.18$ ) and did not differ by wind direction (K-W ANOVA $\left.\chi^{2}=1.25, \mathrm{P}=0.535\right)$.

Mean passage rates for all three species under different combinations of wind direction and front presence differed significantly (Sharpshinned Hawk df = 3, F = 6.49; Broad-winged Hawk df = 3, F = 12.96; American Kestrel df $=3, F=16.15$, all $\mathrm{P}<0.001$ ). Results of Tukey tests differed among species, but general patterns were similar (Fig. 2). Hawk passage rates were highest on days with north winds, but not necessarily on days during cold front events.

We tested whether hawks flew lower on days with north winds with an ANOVA on mean height of hawks observed during north, east and south winds. Mean height of hawks observed under different wind conditions differed significantly for all three species (Sharp-shinned Hawk df $=2 \mathrm{~F}=48.11$; Broad-winged Hawk df $=2 \mathrm{~F}=17.71$; American Kestrel $\mathrm{df}=2, \mathrm{~F}=35.92$, all $\mathrm{P}<0.001)$. In all cases, Tukey tests showed that birds fly higher during east winds vs. north winds (Fig. 3).

\section{DISCUSSION}

Upon reaching the northern coast of the Gulf of Mexico during southbound autumn migration, hawks have several options regarding 


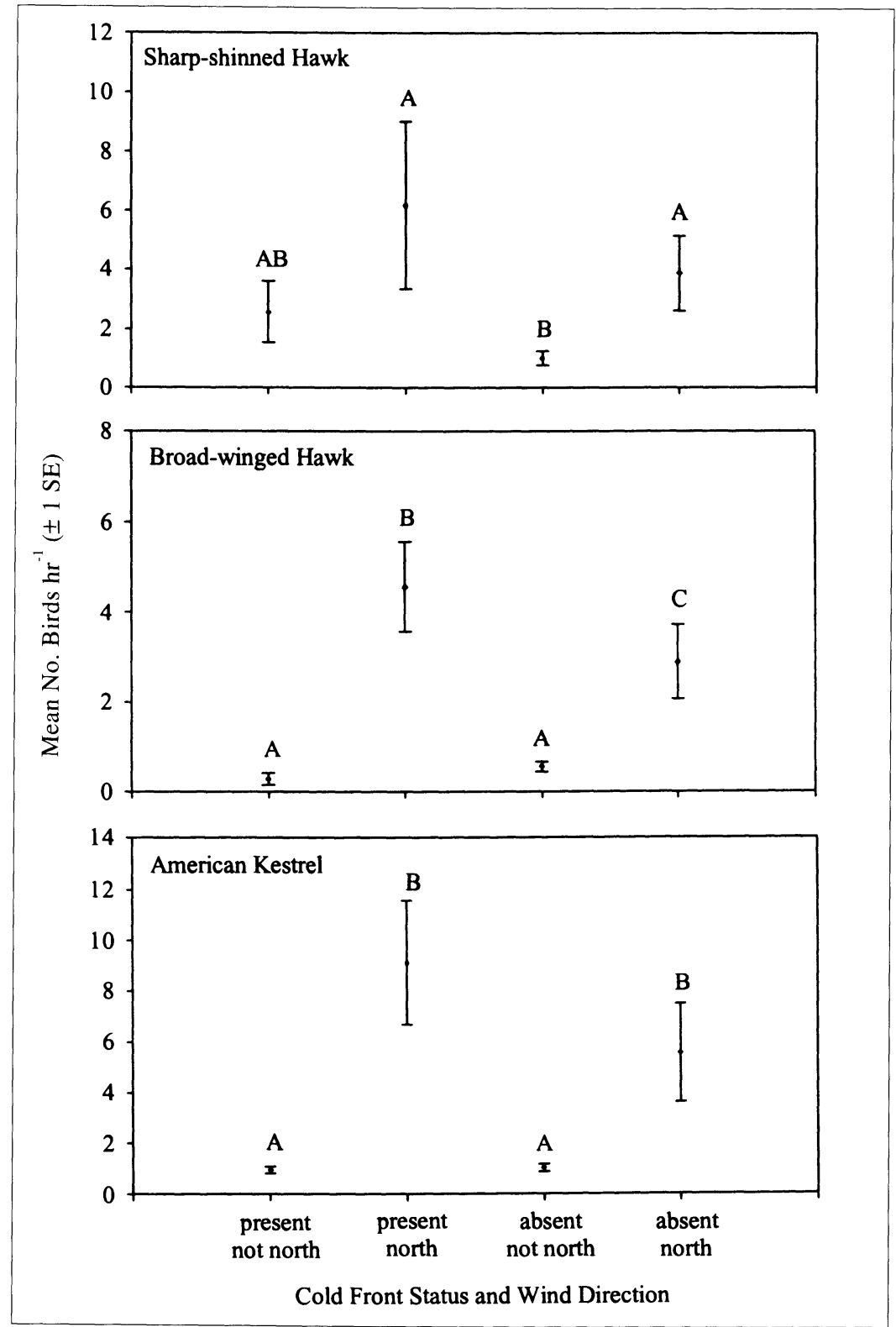

Figure 2. Mean autumn passage rates $( \pm 1 \mathrm{SE})$ of raptors during four weather conditions at Ft. Morgan, Alabama. Sample sizes for each condition (number of days for which passage rates were calculated) are as follows: cold front present/ winds not north 6; cold front present/winds north 24; cold front absent/winds not north 65 ; cold front absent/winds north 26 . For each species, means of error bars that share a letter are not significantly different. Note the change in scale on the $\mathrm{y}$-axis for the three species. 
how to proceed. Since our focal species do not cross the Gulf of Mexico (at least not directly from the northern Gulf coast), these migrants could turn east, west, or cease migrating altogether. The latter is not an option for Broad-winged Hawks, as they do not winter regularly in North America. Most of the hawks (> $80 \%$ for species discussed here) observed at Ft. Morgan during autumn headed west. Why they should do so is not necessarily obvious, as fair numbers of hawks are counted in the Florida Keys during autumn (HawkWatch International, unpubl. data), and Ft. Morgan lies closer to a peninsular Florida migration route than the Texas route. That many of the Sharp-shinned Hawks and American Kestrels may be near their wintering areas should not necessarily influence their flight direction. In fact, if they are near the end of their migration and simply stop heading south because they have reached the Gulf of Mexico, one might predict an equal number of birds heading east and west. Lacking details of where individuals observed at Ft. Morgan come from and where they are ultimately headed, we can

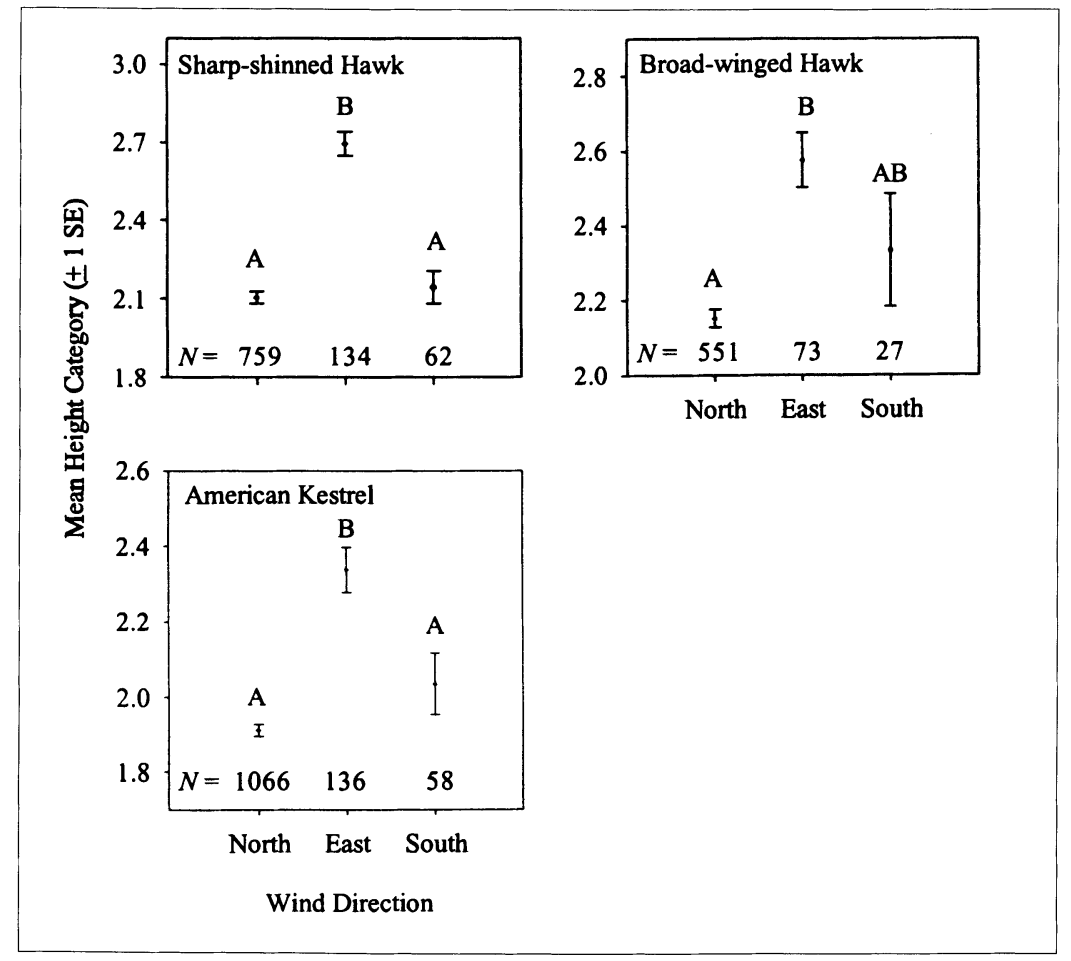

Figure 3. Mean height category ( $\pm 1 \mathrm{SE})$ of passing raptors under different wind conditions during autumn at Ft. Morgan, Alabama. Height categories are: $1=<$ $20 \mathrm{~m} ; 2=20-40 \mathrm{~m} ; 3=>40 \mathrm{~m}$. Sample sizes are given below each error bar, and represent the number of hawks observed under each condition. For each species, means of error bars that share a letter are not statistically different. 
only state that these birds apparently winter mostly west and southwest of our study site. Conversely, the predominant direction of Merlins at Ft. Morgan is eastward, although sample sizes of Merlin were comparatively small and the $\mathrm{z}$-score, although suggestive, is technically not significant $(\mathrm{P}=0.052)$.

We observed more hawks at Ft. Morgan when the wind had a northerly component. Although effects of cold fronts along the Gulf coast (in terms of decreased temperature, increased pressure, etc.) are not as pronounced as in more northerly areas, cold fronts appear to influence on the numbers of hawks observed at Ft. Morgan. Days with a combination of a cold front and north winds produced significantly more observations of Broad-winged Hawk, but not Sharp-shinned Hawk or American Kestrel. In most cases, it is clear that fewer hawks were observed on days without northerly winds, independent of the presence of a cold front. These observations are consistent with results from many other studies, and suggest that hawks mainly arrive on the Gulf coast as a result of riding tail winds that bring birds closer to their wintering areas. Upon reaching the Gulf coast, however, north winds put birds at risk of being blown out to sea, and they must alter their behavior to continue migrating.

How hawks alter their flight behavior is evidenced by our finding that hawks flew, on average, significantly higher during east winds than during north winds. This finding is consistent with studies from the northeastern US, where birds flew higher in winds that took them in the appropriate direction (presumably because wind speed tends to increase with height), though in other studies the appropriate direction was south or southwest. Sharp-shinned Hawks and American Kestrels also flew lower during south winds than on north winds, although relatively few hawks were observed during south winds. However, birds migrating on south winds also tended to fly lower than those observed during east winds. We suspect that this is due to birds trying to avoid being blown over Mobile Bay to the north. Hypotheses about the mean height at which hawks fly under different wind conditions relative to the Gulf of Mexico and Mobile Bay could be tested at inland sites with the aid of radar. Our observations at Ft. Morgan suggest that at inland sites hawks will fly at similar heights on both east and north winds.

As several radar studies have made clear, studies based on observations made by ground-based observers with binoculars should be interpreted cautiously. Beyond a certain height, which varies by observer and weather conditions, migrating hawks are often not detectable. Thus, a day with no cloud cover and seemingly few hawks may, in fact, be a day with typical or even heavy migration traffic at high altitudes that goes undetected. Migrating hawks at Ft. Morgan were not counted at times because they were flying high against a clear blue sky, but how 
common this was is obviously impossible to know without additional data, which could be collected with radar. Sharp-shinned Hawks fitted with radio-transmitters at Ft. Morgan occasionally rose to heights rendering them invisible against a clear sky, even with $8 x$ binoculars (Woltmann 2001). Nonetheless, our observations are consistent with the established notions that hawks ride tail winds at greater heights than other winds, and descend when winds put them at risk of being blown out over large bodies of water. Throughout much of North America in autumn, winds with a northerly component would be considered favorable to migrating hawks, and it has been shown that hawks fly highest on winds taking them in the desired direction. North winds do bring the greatest number of migrant hawks to Ft. Morgan during autumn, but Sharp-shinned Hawks, Broad-winged Hawks and American Kestrels apparently avoid the Gulf of Mexico by turning west and flying lower on winds that could blow them out to sea.

Hawk migration monitoring is needed along the Gulf of Mexico, especially at sites that employ both visual and radar observations. Both the origin and destination of autumn raptor migrants passing along the Gulf coast remain imperfectly known, and analyses of band encounters and studies of birds with satellite transmitters will improve our knowledge of migration patterns of different populations. Our observations of the less abundant species suggest that the patterns found in this study may not hold true for all raptors that migrate through Ft. Morgan (e.g., Merlin.).

\section{ACKNOWLEDGMENTS}

Frank Moore, Paul Hamel, Susan Walls and two anonymous referees offered constructive comments on earlier drafts of this manuscript. Our research was supported by The University of Southern Mississippi. The work of SW was additionally supported by a Hawk Mountain/Carl Zeiss Research Award, a Bergstrom Award (Association of Field Ornithologists) and the Birmingham Audubon Society. The work of DC was additionally supported by Sigma-Xi through a Grant-in-aid of research. The Bon Secour National Wildlife Refuge and Fort Morgan Historic Site kindly allowed us to work on their properties. Craig Fosdick and Scott Rush endured an impressive amount of heat and blinding sun to count hawks. The Migratory Bird Group at The University of Southern Mississippi provided important comments on all aspects of this project.

\section{LITERATURE CITED}

Alerstam, T. 1978. Analysis and a theory of visible bird migration. Oikos 30:273-349.

Allen, P.E., L.J. Goodrich, and K.L. Bildstein. 1996. Within- and among-year effects of cold fronts on migrating raptors at Hawk Mountain, Pennsylvania, 1934-1991. Auk 113:329-338. 
Anders, B.A. 1991. Migration of Sharp-shinned Hawks in the Dry Tortugas, Florida. Wilson Bulletin 103:491-492.

Evans, P.R., and G.W. Lathbury. 1973. Raptor migration across the straits of Gibraltar. Ibis 115:572-585.

Fuller, M.R., W.S. Seegar, and L.S. Schueck. 1998. Routes and travel rates of migrating Peregrine Falcons, Falco peregrinus, and Swainson's Hawks, Buteo swainsoni, in the Western Hemisphere. Journal of Avian Biology 29:433-440.

Hall, L.S., A.M. Fish, and M.L. Morrison. 1992. The influence of weather on hawk movements in coastal northern California. Wilson Bulletin 104:447-461.

Hussell, D.J.T. 1985. Analysis of hawk migration counts for monitoring population levels. Pp. 243-254, In M. Harwood (Ed.). Proceedings of Hawk Migration Conference IV. Hawk Migration Association of North America, CT.

Kerlinger, P. 1984. Flight behaviour of Sharp-shinned Hawks during migration. II: Over water. Animal Behaviour 32:1029-1034.

Kerlinger, P. 1989. Flight strategies of migrating hawks. University of Chicago Press, Chicago, IL.

Kerlinger, P., V.P. Bingman, and K.P. Able. 1985. Comparative flight behaviour of migrating hawks studied with tracking radar during autumn in central New York. Canadian Journal of Zoology 63:755-761.

Kerlinger, P., and S.A. Gauthreaux, Jr. 1984. Flight behaviour of Sharp-shinned Hawks during migration. I: Over land. Animal Behaviour 32:1021-1028.

Kerlinger, P., and S.A. Gauthreaux, Jr. 1985. Flight behavior of raptors during spring migration in south Texas studied with radar and visual observations. Journal of Field Ornithology 56:394-402.

MacRae, D. 1985. Over-water migration of raptors: A review of the literature. Pp. 75-88 in Harwood, M. (Ed.), Proceedings of Hawk Migration Conference IV. Hawk Migration Association of North America, CT.

Millsap, B.A., and J.R. Zook. 1983. Effects of weather on accipiter migration in southern Nevada. Journal of Raptor Research 17:43-56.

Richardson, W.J. 1975. Autumn hawk migration in Ontario studied with radar. Pp. 41-58, In Proceedings of the North American Hawk Migration Conference. Hawk Migration Association of North America, CT.

Richardson, W.J. 1978. Timing and amount of bird migration in relation to weather: a review. Oikos 30:224-272.

Richardson, W.J. 1990. Timing of bird migration in relation to weather: updated review. Pp. 78-101, In E. Gwynner (Ed.) Bird migration: Physiology and ecophysiology. Springer-Verlag, Berlin, Germany.

SPSS. 1999. SPSS 9.0 for Windows ${ }^{\circledR}$. SPSS Inc., Chicago, IL.

Tabachnick, B.G., and L.S. Fidell. 1996. Using multivariate statistics. Harper Collins College Publishers, New York, NY.

Titus, K., and J. Mosher. 1982. The influence of seasonality and selected variables on autumn migration of three species of hawks through the central Appalachians. Wilson Bulletin 94:176-184.

Woltmann, S. 2001. Habitat use and movements of Sharp-shinned and Cooper's Hawks at Fort Morgan, Alabama. North American Bird Bander 26:150-156.

Zar, J.H. 1999. Biostatistical Analysis, 4th Ed. Prentice Hall, Upper Saddle River, NJ. 